\title{
O INIMIGO DO POETA COMO UM MACACO
}

\author{
Paula da Cunha Corrêa
}

RESUMO: A study of the the fable of the Fox and the Ape (Aesop 38 Chambry, 81 Perry?) narrated in the iambi of Archilochus. The commentary on the fragments (Arch. 185-187W) discusses their ancient sources, textual difficulties, and the modern reconstructions of Archilochus' "ainos" via Aesop and Babrius (a). The "ethos" of the fox and of the ape in antiquity, examined in section b), illuminates the manner in which the poet attacks his enemy in this iambus.

PALAVRAS-CHAVE: Arquíloco, lírica grega arcaica, fábula arcaica.

fr. $185 \mathrm{~W}$

5

$$
\begin{gathered}
\text { pi/qhkoj h)/iei qhri/wn a)pokriqeilj } \\
\text { mou=noj a)n (e)sxatih/n, } \\
\begin{array}{c}
\text { tw=n d } \quad \text { a) }=\text { r Ja)/w/phc kerdalh= sunh/nteto, } \\
\text { puknoln e)/xousa no/on. }
\end{array} \\
\begin{array}{c}
\text { O macaco ia, apartado dos animais, } \\
\text { só, aos confins, }
\end{array} \\
\text { quando o encontrou a raposa astuta, } \\
\text { de mente densa. }
\end{gathered}
$$

Nesses quatro versos do fragmento 185.3-6W de Arquíloco, após a interpelação feita ao "filho do arauto", inicia-se o aînos propriamente dito. ${ }^{1}$ A construção dos dois dísticos, conforme o estilo arcaico, contrasta os dois agentes. Logo de início, o macaco é qualificado no verso 3 por um particípio, ele caminhava "apartado" (apokritheís) dos outros animais. ${ }^{2}$ Não sabemos, a princípio, se ele parte por vontade própria ou se é "exilado". ${ }^{3}$ Que eu me lembre, não há, porém, na literatura desse período (e até bem mais tarde), registro de um personagem que procure, por vontade própria, afastar-se dos seus pares, isolar-se. Basta lembrarmos os sofrimentos de Odisseu e Ájax, as saudades de ambos pelas suas respectivas terras e companheiros. Buscar a solidão seria algo incompreensível para um grego dessa época. Aqueles que partiam sós o faziam por necessidade, por haverem sido repudiados por seus concidadãos ou por um deus. Portanto, mais verossímil é a hipótese de que o macaco da fábula de Arquíloco tenha sido rechaçado pelos outros animais e, assim, compreende-se facilmente o quarto verso em que se diz que ele foi "só, aos confins".

O adjetivo moûnos (v.4 "só"), que qualifica o macaco, é início de verso freqüente na épica, enquanto an' eskhatíen ("aos confins"), apesar de não atestada, também parece ser formular. ${ }^{4}$ É evidente que, por motivos métricos, não encontraríamos fórmulas homéricas no primeiro verso de cada dístico (nos trímetros jâmbicos). Mas isso não quer dizer que a linguagem nesses versos fosse menos tradicional. Pelo contrário, o simples fato de encontrarmos fórmulas nos dáctilos indica que, se o nosso corpus desse gênero de poesia fosse maior, provavelmente encontraríamos fórmulas jâmbicas nos epodos. ${ }^{5}$

Após o adjetivo, a locução an' eskhatíe, traduzida como "aos confins", indica a região para a qual parte o macaco. A eskhatíe é uma região limítrofe, uma fronteira, o termo de um campo ou a ponta de uma baía $(O d .2 .391,10.96,24.150)$. Nas extremidades do mundo, à margem da civilização, habitam "monstros". São seres selvagens, como os titãs Briareu, Cotos e Giges que, após sua derrota, são forçados por Zeus a viverem "nos limites da grande terra" (ep' eskhatíei; Hesíodo, Th. 622). O Ciclope da Odisséia

\footnotetext{
Paula da Cunha Corrêa é professora da Faculdade de Filosofia, Letras e Ciências Humanas da USP

Não há grandes divergências textuais entre as edições desses versos, o único (se não considerarmos a impressão do iota como ad ou subscrito) concerne a grafia de kerdale/h, forma épica, segundo Page (1964, p.142), presente em Eustácio (in Hom. p.1768.65 ex Eren. Phil), Et. Gud. (i.48.18 de Stephani), Eliano (N.A. 6.64), Suda (iii.99.2 Adler) e, nos textos modernos, em Schneidewin (1838), Bergk (1882, 19152), Edmonds (1931), Treu (1959), Lasserre-Bonnard (1958), Page (1964, p.141), Tarditi (1968), Gerber (1970); kerdalh= de Ps-Amônio (de adfin. vocab. diff. 18, p.5 Nickau) e Apostólio (praef. Paroem. Gr. I.i.236.6) em Liebel (1812), Hiller (1890), Hoffmann (1898), Diehl $\left(1926^{1}, 1936^{2}, 1952^{3}\right)$, West $\left(1989^{2}\right)$, Bossi (1990; p.210). Para um comentário dos primeiros versos do fr. 185W de Arquíloco, cf. Corrêa (1998b, p. 249-262).

${ }^{2}$ u(pokriqeilj em Apostol. Praef. (Paroem. Gr. I.i.236.6).

${ }^{3}$ As traduções de Lasserre-Bonnard (1958), Tarditi (1968), Rankin (1977, p.92) dão a entender que se trata de uma exclusão, enquanto as de Hauvette (1905, p.176), Edmonds (1931), Treu (1959) e West (1993) exprimem apenas um afastamento.

${ }^{4}$ Cf. e)p ) e)sxati/hn (Od. 24.150) e e))p ) e)sxati/hi (Od. 2.391, 9.182, 10.96; Hesíodo, Th. 622) antes da cesura masculina. Page (1964, p.142) a considera expressão formular.

${ }_{5}^{5}$ Page $(1964,142)$ indica algumas frases ou expressões que lhe parecem "tradicionais": v.5 t\%=d ) a)=r ) )seria uma adaptação de tw=i d )a)/ra; sunh/teto parece-lhe "absolutamente convencional". Gerber (1970, p.38) nota que a forma a)=ra ocorre pela primeira vez em Arquíloco, nessa passagem e em 3 outros versos (cf. Denniston, 1954², p.44).
} 
(9.182) que também mora "nos confins" não conhece as leis dos homens. Essa noção nos será útil quando quisermos apreender qual, para os gregos, era o caráter convencional do macaco (cf. infra).

No segundo dístico, a raposa encontra o macaco, e sua entrada em cena é marcada por uma ligeira gravidade (ameaça?) expressa pelo ritmo mais pesado no início do verso. A ordem dos atributos é agora invertida: a raposa é primeiro qualificada por um adjetivo (v.5) e, no verso seguinte, por uma oração participial. Opõe-se em quiasmo o macaco "só" (v.4 moûnos) à raposa "astuta" (v.5 kerdalê). A comparação parece, a princípio, esdrúxula. Qual a relação ou o contraste possível entre a esperteza de uma e a solidão do outro? Sem recorrermos ainda às demais fábulas da tradição greco-latina em que o macaco figura como protagonista, poderíamos lembrar que o nosso termo "idiota" vem da raiz do adjetivo grego ídios, que qualifica algo como sendo "privado" ("particular"), em oposição ao que é "público", "comum". Daí, o que é ídios é "distinto", "separado", "peculiar" ou "excêntrico". Quase três séculos mais tarde, a natureza própria do homem foi definida como sendo "política": o homem, esse animal da pólis, vive na companhia de seus semelhantes e ocupa-se do que lhes é comum. Se a solidão do macaco é opção sua, diríamos talvez sem anacronismo que essa característica (sua "alienação") já o distingue como inferior à raposa.

A caracterização da raposa como "astuta" (kerdalê), comum a muitas tradições, indica que desse encontro com o macaco, visando o "lucro" (kérdos), ela levará a melhor. E na Grécia arcaica, cuja força econômica derivava do comércio, não havia a princípio (e de modo geral) censura contra aquele que levava "vantagem" nas transações. Pelo contrário, nem o pio narrador da Ilíada (6.234-6) consegue conter-se diante da "falta de juízo" de Glauco que, na ritual troca de armas com Diomedes, sofre prejuízo. A personagem mais astuta da literatura grega talvez seja Odisseu, justo quem derrotou o selvagem Ciclope nas extremidades do mundo civilizado. Quando Odisseu, sem reconhecer Palas Atena, a sua deusa protetora, inventa-lhe uma estória de modo a ocultar sua verdadeira identidade, ela afetuosamente responde que só alguém mais astuto que ele (i.é, ela própria) seria capaz de enganá-lo (Od. 13.291ss). ${ }^{6}$

Se o macaco está "só" (v.4) porque caminha "apartado dos animais" (v.3), a raposa é "astuta" (v.5) por ter "mente densa" (v.6). ${ }^{7}$ Nessas duas orações participiais, o movimento do macaco que resulta na sua separação (theríon apokritheís), contrasta com a solidez fixa da raposa que possui acirrada mente (pyknòn ékhousa nóon). Pyknós é aquilo que é "denso" ou "sólido" por ter as suas partes reunidas em um todo compacto (LSJ, s.v.). Assim são os objetos e as formações que são firmes e fortes por haver um espaço mínimo entre os elementos que os constituem (malhas, camas, casas, falanges) ${ }^{8}$ e, no âmbito da natureza, o que parece ser uma massa compacta (esponjas, penas, folhagens, nuvens). ${ }^{9}$ A rapidez ou alta frequiência de um movimento também gera densidade e, a partir do quinto século a. C., encontramos passagens em que chuvas, nevadas e intervalos breves de um tetracorde são qualificados como pyknoí: as rotações velozes, como as de asas e rodas aceleradas, chegam a criar a ilusão de um volume imóvel. ${ }^{10}$

Se na Ilíada (15.461) Zeus tem uma "mente densa" (pykinòn nóon) como a da raposa de Arquíloco, são também "densas" (pyknaî) as suas phrénes ${ }^{11}$ que, apenas sob o feitiço de Afrodite, são obscurecidas pelo desejo (Eros) no célebre episódio em que Hera o seduz para distraí-lo da guerra e para favorecer as tropas gregas (Il.14.294). Helena apresenta Odisseu a Príamo e aos anciãos troianos na Ticoscopia (Il. 3.200-202) como o "mais astuto" dos heróis gregos, o polýmetis que "conhece toda espécie de dolos e pensamentos densos" (médea pykná). ${ }^{12}$ A Mêtis é a forma de astúcia e inteligência multiforme característica da raposa, de Odisseu, de Zeus (que a possui por tê-la engolido), de outros seres como o polvo, das artes e dos ofícios de Atena e Hefesto, de caçadores e médicos (cf. Detienne e Vernant, 1974).

Píndaro, o poeta do louvor (epaínos) e feroz adversário de Arquíloco, censura os seus jambos ferinos na Segunda Ode Pítica dizendo (vv.52-56): "a mim, é necessário/ fugir da eloqüente mordida do maldizer./ Pois vi de longe, muita vez em necessidade/ o satírico Arquíloco engordando/ com ódios de pesadas palavras". ${ }^{13}$ Píndaro (v.56), ao contrário, prefere enriquecer. Duas estrofes adiante (v.73ss), após mencionar a feiúra do macaco, ele questiona a vantagem (kérdos) que obtêm aqueles que, com o temperamento da raposa (kerdaléos), caluniam e fazem intrigas. Não estaria Píndaro ainda pensando nos poetas jâmbicos (psogeroí) e, particularmente, em Arquíloco que acaba de mencionar? Parece tratar-se de uma referência justamente à Fábula da Raposa e do Macaco (RANKIN,1977, p.93).

Simônides em um jambo misógino (cf. infra) e Arquíloco, em dois versos que talvez fizessem parte de um aînos, já haviam indicado facetas negativas dessa inteligência multiforme (Arq. fr. 201W:

\footnotetext{
${ }^{6}$ Cf. kerdaléos também com referência ao discurso (Od. 6.148) ou mente (Od. 8.548) de Odisseu.

7 É possível que a frase pyknòn ékhousa nóon ("tendo uma mente densa") fosse, como dizem Page (1964, p.142) e Fowler (1987, p.19), uma fórmula pentamétrica: na Ilíada (15.461), Zeus tem "mente densa" (pykinòn nóon). Cf. também a Teogonidéia (pistòn ékhousi nóon 74, koûphon ékhonta nóon 580, esthlòn ékhoimi nóon 792) e a Ilíada 24.282 (pykinà phresì méde’ ékhontes). ${ }^{8}$ Od. (14.521); Il.(9.621), Od.(7.340); Il.(4.281, 7.61, 11.309, 13.130); Xenofonte (17).

${ }^{9}$ Platão (Ti. 75b); Il.(11.454, 23.879), Od.(5.53); Il.(18.320, 21.245), Od.(5.471, 10.150, 14.473, 19.439, 19.520), Hesíodo (Erga

${ }_{553) \text { Platão }}$

${ }^{10}$ Sófocles (fr.636, Aj.1208), Eurípides (Andr.1129), Aristóxeno (Harm.p.24M), Plutarco (de mus. 2.1135b), Safo (fr.1.11L-P), Sófocles (fr.871.1). Nota-se que na leitura da Ode de Safo, a única fonte arcaica entre as aqui citadas, é possível que o adjetivo refira-se apenas à densidade das asas e não ao seu movimento.

${ }^{11}$ Em Homero e nos líricos arcaicos, é difícil fazer uma distinção entre o emprego de nóos e phrénes, sedes de percepção intelectiva e emotiva, os dois termos sendo quase intercambiáveis na literatura desse período, cf. Corrêa (1998a, p.31-38).

${ }^{12}$ Cf. também Il.(24.674): pukinal fresil mh/de )e)/xontej.

${ }^{13}$ Píndaro (P. II.52-56): e)mel del xrewln/ feu/gein da/koj a)dinoln kakogoria=n./ ei)=don galr e(kalj e)wln tal po/ll ) e)n a)mhxani/\#/ yogeroln A)rxil/oxon barulo/goij e)/xqesin/ piaino/menon:
} 
po/ll ) oi $=d \quad$ ) a)lw/phc, a)\|l ) e)xi=noj e(ln me/ga, "muitas coisas sabe a raposa, mas o porco-espinho, uma grande"). Nota-se, mais tarde, uma crescente hostilidade contra este tipo de esperteza que passa a ser associada à sofística e política (DETIENNE \& VERNANT, 1974). Platão (R. 365c), cuja moralidade está longe do senso comum, diz que a raposa do sabidíssimo Arquíloco é astuta (kerdalée) e multifacetada (poikíle). Por volta da mesma época, Eurípides apresenta um Odisseu "sofista" na tragédia. Pois a poikilía, atributo da raposa e do herói, é também característica do discurso sofístico e do mundo às avessas instaurado pelos tiranos. ${ }^{14}$

Díon Crisóstomo também refere-se às raposas de Arquíloco em duas passagens. Uma delas encontra-se no discurso Sobre a desconfiança (Perì apístias 74.15) onde, após citar um número de figuras políticas e lendárias que cometeram perjúrio, rompendo pactos ou promessas, ele nos conta que, segundo o lacedemônio Lisândro, meninos devem ser enganados com ossos e bolas, e os adultos, com juras e palavras (hórkois kaì rhémasin). ${ }^{15}$ Então Díon pergunta: “e a astuta raposa, segundo Arquíloco, é diferente?"16

Embora Díon caracterize a raposa aqui com o mesmo adjetivo empregado por Arquíloco no fragmento $185 \mathrm{~W}$, será que ele está pensando especificamente esse poema? Nos quatro versos de Arquíloco preservados em outras fontes, não há menção de perjúrio, apesar da raposa, por ter "mente densa", parecer estar tramando algo. Mas, em virtude do uso do mesmo epíteto, a maioria acredita que Díon esteja referindo-se a este aînos de Arquíloco. Depois, como em todo o seu discurso Díon mostra que os falsos amigos são capazes de mal maior do que os inimigos declarados (Or. 74.3), com um argumento circular, os comentadores deduzem que, na Fábula da Raposa e do Macaco narrada por Arquíloco (fr. 185-7, 225, 311W), a raposa, fingindo ser amiga do macaco, persuade-o a entrar em uma armadilha (Esopo 38 Chambry. e COHOON, 1961-85, p.223 N.6).

Nota-se, porém, que logo no parágrafo seguinte Díon faz outra referência a Arquíloco mencionando a ruptura do pacto nupcial, o rompimento do acordo "do sal e da mesa". Ele diz que "para Arquíloco, o sal e a mesa de nada valeram quanto ao pacto nupcial" (Or. 74.16). ${ }^{17}$ Aqui o autor parece ter em mente outros versos de Arquíloco, precisamente o fragmento $173 \mathrm{~W}$ que, para a maior parte da crítica, faz parte da Fábula da Raposa e da Águia (fr. 172-181): o(/rkon d ) e)nosfi/sqhj me/gan/ a(/laj te kail tra/pezan, "rompeste o grande pacto:/ o sal e a mesa".

É possível que, ao mencionar a raposa de um aînos, Díon tenha se lembrado da raposa de outro (a não ser que os fragmentos pertencessem a um só poema). De qualquer forma, segundo Arnim (1859-31), Díon teria feito esse discurso em exílio e, por isso, a questão principal é a da traição entre amigos. Após arrolar tantos males causados por falsos amigos, Díon pergunta retoricamente (Or. 74.23): “O que então?", “devemos escolher a vida de um animal (theríou bíon) e viver só (éremon)?” Ele mesmo então responde que não devemos optar por uma vida animal, mas pela de um homem prudente (phrónimos); a solidão (eremía) sendo melhor e mais segura quando é sem temor e isenta de solicitude pelo que é relativo à coletividade (khorìs koinón prosohkês). Ao ler esse texto com os versos de Arquíloco em mente, lembramos logo do macaco que, "ia, apartado dos animais, só (mô̂nos), aos confins" (fr. 185.1-2). Quanto à escolha de vida, um ser humano que literalmente "escolhe" ser um macaco em sua próxima reincarnação é Tersites, no "Mito de Er" de Platão (R. 620c). Discutiremos essas associações mais tarde. Vejamos antes a segunda referência à raposa de Arquíloco em Díon.

Na Oração 55 de Díon, que também deve ser sido escrita durante o seu período de exílio, ele discute de que modo podemos considerar Homero como sendo o "professor" de Sócrates. No início, respondendo à questão da diferença entre os respectivos discursos (poesia/prosa) do poeta e do filósofo, Díon cita Arquíloco e Estesícoro que são "seguidores de Homero", embora empreguem formas métricas distintas. Quanto às semelhanças, Homero e Sócrates seriam moderados e modestos, tratavam dos mesmos temas (a virtude e o vício humano, os erros e acertos, a verdade e o engano), e concordavam que "a maioria opina e os sábios conhecem" (Or. 55.8-9). Logo em seguida, o interlocutor pergunta se poderíamos comparar Homero com Sócrates no tocante à habilidade de criar símiles e comparações: Homero lança mão do "fogo, vento, mar e águias, touros, leões etc.", ao passo que Sócrates recorre aos ceramistas e coureiros. Díon (Or. 55.10) responde: "Sim, meu caro, se também comparamos a raposa de Arquíloco aos leões e leopardos [de Homero] e dizemos que é nada ou pouco inferior". ${ }^{18}$

A citação de Díon informa-nos mais sobre o aînos em Arquíloco e a sua função do que sobre a raposa. A fábula arcaica não é um gênero à parte, mas um recurso comparável ao símile, uma figura de linguagem inserida no poema. Tanto no aînos, quanto no símile, o poeta exemplifica uma situação do mundo humano com uma imagem ou um acontecimento paralelo que ocorre no âmbito da natureza, seja o

\footnotetext{
${ }^{14}$ Cf. Carvalho Franco (Parte de trabalho inédito proferido no encontro acadêmico A Escrita no Mundo Antigo (MAE, 1998) "Escrita e oralidade; aspectos de uma teoria da linguagem em Platão, Fedro 274c-276a .): "No processo de degradação da pólis, exposto por Platão na República, os regimes de governo aparecem, de modo crescente, determinados no plano do sensível, estando, por isso mesmo, sujeitos a deformações e movimentos desordenados. (...) Na democracia as condutas e valores centrais da cultura aparecem invertidos, assim apoderando-se da alma dos jovens (...) Na tirania, as inversões multiplicam-se e atingem o núcleo da vida política: governados assemelham-se a governantes, governantes a governados, quem submete-se ao governante é denominado

servo voluntário (ethelódoulos).
${ }_{15}$ Lançar "ossos" (astragáloi) era um jogo típico dos garotos.

${ }_{16}$ Lançar "ossos" (astragáloi) era um jogo típico dos garotos.
Peri apístias 74.15 , ii.197.16 von Arnim h( kerdalh= del a)lw/phc e(te/ra ti/j e)sti paral A)rxilo/xou;

${ }^{17}$ Díon (Or. 74.16): toln A)rxi/loxon ou)deln w)/nhsan oi( a(/lej kail h( tra/peza prolj thln o(mologi/an tw=n ga/mwn (...).

${ }^{18}$ Díon (Or. 55.10) Ei)/per ge, w=) maka/rie, kail thln A)rxilo/xou a)lw/peka toi=j le/ousin kail tai=j parda/lesi paraba/llomen kail ou)deln h)\ $\mathrm{mh}$ polul a)podei=n famen.
} 
protagonista um fenômeno natural (fogo, ventos, ondas) ou um animal. Mas será que o aînos é mesmo uma espécie de símile? Qual a diferença? A primeira (e a mais evidente) é que os símiles não contêm nada inverossímil: os leões homéricos perseguem rebanhos, mas não falam, como os das fábulas. As cenas dos símiles são realistas, elas nada têm de mágicas, como os cavalos de Aquiles e o universo fantástico da Odisséia.

Assim como Díon $(O r .74 .9,11)$ associava aqueles que rompiam pactos (entre os quais incluía a "astuta" raposa de Arquíloco) à panourgía e ponería, também em Eliano (N.A. 6.64) a "astúcia" da raposa, relacionada a essa "esperteza" (ponería), adquire conotação pejorativa: "a raposa é um animal esperto (ponerón); por isso também os poetas gostam de chamá-la de a Astuta (kerdalée)". ${ }^{19}$ Hesíquio apenas glosa "astuta" por "raposa", mas lemos no Suda (iii.99.2 Adler): "astuto (kerdaléos) = multifacetado (poikílos), velhaco, pois a raposa é astuta e uma ladra". ${ }^{20}$

São Basílio, em um discurso endereçado aos jovens, argumenta que "se desprezamos os bens e não damos valor aos prazeres estéticos, buscaremos a bajulação e a adulação, almejaremos a astúcia (tò kerdaléon) e as múltiplas facetas (tò poikílon) da raposa de Arquíloco?"21 A reposta é evidentemente negativa e o Santo explica: nada menos sábio do que "viver conforme a opinião" (pròs dóksan zdên), "e examinar o que agrada à maioria", em vez de ter uma "razão correta" (orthòs lógos) como guia. "Aquele que não vive desse modo, em que difere do sofista do Egito que se transforma, quando quer, em planta, animal, fogo, água, e todas as coisas?" O "sofista do Egito" é Proteu. São Basílio empresta a imagem de Platão (Eutidemo 288B) que assim chamou os sofistas de sua época. E no final desse parágrafo, compara-se o bajulador ao polvo, outro animal que, como a raposa, é famosa pela sua Mêtis e essa forma de astúcia multifacetada (poikílon) - pois ele muda de cor conforme a terra subjacente. ${ }^{22}$

Por fim, vemos que, segundo as fontes mais antigas, essa forma de "astúcia", salvo raras exceções, era estimada no período arcaico, e creio que é nesse sentido que devemos compreender a figura da raposa nesse poema de Arquíloco. A conotação pejorativa de kerdaléos (e do animal que a possui como atributo típico) começa a tornar-se mais freqüente a partir da sua associação com a dóksa em Platão, e com a atuação dos sofistas. Em Díon, Eliano e São Basílio, passa a ser uma "esperteza" da massa (hoi polloí), daquele que é panourgós e ponerós, uma característica dos falsários "multifacetados" (poikíloi).

\section{RECONSTRUCÕES DO AÎNOS DE ARQUÍLOCO VIA ESOPO E BÁBRIO}

Os fragmentos 185-87W de Arquíloco são os que, segundo Edmonds (1931), Treu (1956), Tarditi $(1968)^{23}$ e West $\left(1989^{2}\right)^{24}$, constituíam a Fábula da Raposa e do Macaco. Mas outras hipóteses também foram feitas, pois os textos foram citados em fontes independentes e a reconstrução da narrativa depende portanto basicamente daquilo que os editores e comentadores imaginam ser a narrativa "original" que resgatam através das versões posteriores em Esopo, Bábrio, ou em outros textos tardios. Façamos, então, um breve resumo dos enredos propostos.

Liebel (1812, p.164-169), seguindo Amônio, já citava conjuntamente os versos 1-6 do fragmento 185W, sendo o seu texto (v.2-6) idêntico ao das edições mais recentes (cf. West $1989^{2}$ ). Ele julgava (como Huschke, 1810) que o poema zomba da prepotência de Licambes e que o aînos narrado corresponde à fábula 39 de Esopo (Chambry):

A)/w/phc kail pi/qhkoj e)n tau)t\%= o(doiporou=ntej peril eu)genei/aj h)/rizon. Pollal del e(kate/rou diecio/ntoj, e)peidhl e)ge/nonto kata/ tina to/pon, e)ntau=qa a)poble/yaj a)neste/nacen o( pi/qhkoj. Th= del a)|w/pekoj e)rome/nhj thln ai)ti/an, o( pi/qhkoj e)pidei/caj au)t\$= tal mnh/mata, ei)=pen: "A)Il' ou) me/llw kla/ein, $o($ (rw=n talj sth/laj tw=n patrikw=n mou a)peleuqe/rwn kail dou/lwn;" Ka)kei/nh prolj au)toln e)/fh: "A)/lal yeu/dou o(/sa bou/lei: ou)deilj galr tou/twn a)nastalj e)le/cei se." Ou(/tw kail tw=n a)ngrw/pwn oi( yeudolo/goi to/te ma/lista katalazoneu/ontai, o(/tan toulj e)le/gxontaj mhl e)/xwsin

A raposa e o macaco, viajando pela mesma estrada, disputavam acerca da nobreza de suas linhagens. Cada um já havia falado muito quando, chegando em um lugar, o macaco olhou ao seu redor e gemeu fundo. A raposa perguntou o motivo do lamento e então o macaco, mostrando-lhe as lápides, disse: "E eu não deveria chorar, vendo os túmulos dos escravos e dos trabalhadores que serviram aos meus antepassados?" Então disse-lhe a raposa: "Minta o quanto quiser, pois nenhum desses aí levantará para contradizê-lo." Assim também gabam-se os homens mentirosos, sobretudo quando não há quem os contradiga. ${ }^{25}$

Se na fábula de Esopo (39 Chambry) o macaco está viajando na companhia da raposa, no aînos de Arquíloco ele está só e parece ter sido expulso (exilado? apokritheís), pois está partindo para os

\footnotetext{
${ }^{19}$ Eliano (N.A. 6.64): $\mathrm{h}(\mathrm{a}) / \mathrm{w} / \mathrm{phc}$ ponhroln $\mathrm{z} \%=0 / \mathrm{n}$ e)stin, e)/nqen toi kail kerdale/hn oi( poihtail kalei=n filou=sin au)th/n.

${ }^{20}$ Hesíquio (kerdalh=: a)lw/phc), Suda (iii.99.2 Adler kerdale/oj: poiki/loj, panou=rgoj. kerdale/h galr $h($ a)lw/phc. Kail kerdw/. ). Cf. também Synag AG I.276, 12 Bachm. (kerdale/h), Fócion (157). Para a raposa como poikílos, veja também Platão (R. 365c supra). ${ }^{21}$ São Basílio (ad adulescentes 9.130-5 p.59 Boulenger): A)llal dh=ta plou/tou meln u(peroyo/meqa, kail talj dial tw=n ai)sqh/sewn $\mathrm{h}$ (donal a)tima/somen, kolakei/aj del kail qwpei/aj diwco/meqa, kail th=j A)rxilo/xou a)lw/pekoj tol kerdale/on te kail poiki/lon;

${ }^{22}$ A raposa de Arquíloco citada por São Basílio (loc. cit.) é bajuladora, o que serve como um argumento a favor da identificação dessa fábula de Arquíloco com a da Raposa e do Macaco eleito rei (Esopo 38 Chambry).

${ }_{23}$ Tarditi (1968) apenas salta o fr. 186W.

${ }^{24}$ West (loc. cit.) sugere que talvez o fragmento $225 \mathrm{~W}$ (pa/relqe, gennai=oj ga/r ei)j. "vem, pois nobre és") também fizesse parte do epodo.

${ }^{25}$ A mesma fábula é versificada por Bábrio (81).
} 
limites da cidade ou da terra (eskhatíes) quando a raposa o encontra. Essa, porém, seria uma diferença menor. O problema é saber por que razão o macaco está só. Não havendo na versão de Esopo um plano ou artifício da parte da raposa, a suas qualidades, a astúcia e "mente densa", serviriam apenas para detectar a mentira do macaco.

Não foram poucos os que seguiram Liebel (1812) em associar essa fábula (Esopo 39 Chambry) ao fragmento $185 \mathrm{~W}$ de Arquíloco. ${ }^{26} \mathrm{Um}$ argumento a favor dessa aproximação e que, aparentemente, ninguém mencionou, é o fato de o poema de Arquíloco ser endereçado a um "filho de arauto". Os aînoi mais antigos eram endereçados a pessoas específicas e tinham aplicações práticas. Assim, uma possibilidade de leitura é que Arquíloco faz troça desse Kerykídes que, seja quem for, ${ }^{27}$ jacta-se de ser nobre, um rei, talvez, enquanto é apenas mensageiro, um leva-e-trás. O poeta, ao vestir a máscara da astuta raposa e colocar o seu inimigo na pele desse macaco, estaria dizendo, em outras palavras, "filho de arauto, arauto é". 81 Perry) ${ }^{28}$.

Outros sugerem que o aînos de Arquíloco seja uma versão da fábula de Esopo (38 Chambry,

e)n suno/d\% tw=n a)lo/gwn z\%/wn pi/qhkoj o)xhsa/menoj kail eu)dokimh/saj basileulj u(p ) au)tw=n e)xeirotonh/qh. a) $\mid w / p h c$ del au $t \%=$ fqonh/sasa, w(j e)qea/sato e)/n tini pa/g\$ kre/aj ke/imenon, a)gagou=sa au)toln e)ntau=qa e)/legen w(j eu(rou=sa qhsauroln au)thl meln ou)k e)xrh/sato, ge/raj del au)t\%= th=j basilei/aj teth/rhke, kail par $\$$ nei au)t\%= lamba/nein. tou= del a)melh/twj e)pio/ntoj kail u(pol th=j pa/gi/doj sullhfqe/ntoj, ai)tiwme/nou te thln a)/w/peka $w(j$ e)nedreu/sasan au)t\%=, e)kei/nh e)/fh: "w)= pi/qhke, sul del toiau/thn pughln e)/xwn tw=n a)lo/gwn z\%/wn basileu/<s>eij;"

$\mathrm{Na}$ assembléia dos animais, o macaco, ao dançar, foi aclamado e por eles eleito rei. A raposa que o invejava, quando viu uma armadilha com carne, levou o macaco até lá. Disse-lhe que havia encontrado um tesouro mas que não o tocou, reservando-o para ele como um privilégio real e o aconselhou a tomar a carne para si. Quando o macaco entrou sem cuidado na armadilha e foi preso, culpou a raposa por lhe ter armado uma cilada. Ela então respondeu: “ Ó macaco, você, com essa bunda, quer ser rei dos animais?". 29

Se essa for a fábula narrada por Arquíloco, identificaríamos o "eu” lírico com a raposa que zomba de um adversário político, hediondo e tolo, que obteve o poder. Como alguns já sugeriram, poderia ser um Leófilo ("amigo do povo"), o demagogo caçoado no fragmento $115 \mathrm{~W}$, ou até mesmo o próprio Licambes. Não há meio de saber se os fragmentos 185-187, 225 e 311W faziam ou não parte de um só poema. Caso contrário, haveria pouca dúvida de que fosse essa a fábula a narrada por Arquíloco. O certo, segundo um escoliasta, é que o seguinte verso de um epodo de Arquíloco (fr. 187W) ${ }^{30}$ Toih//nde d ) w)= pi/qhke thln pughln e)/xwn (ó macaco, e com essa bunda) foi parodiado por Aristófanes nos Acarnenses (v.120): Toio/nde d ), w)= pi/qhke, toln pw/gwn ) e)/xwn: (“ó macaco, e com essa barba!").

Além dessas duas propostas de leitura, há sugestões ainda mais elaboradas. Lasserre (1950, ep. 7) reúne esses mesmos fragmentos em um só epodo e refere-se também às fábulas 38 \& 39 de Esopo (Chambry) e Bábrio $(81,130)$ como paralelos possíveis, mas ele acrescenta pelo meio vários outros fragmentos e, acreditando tratar-se de um "epodo satírico dirigido a Péricles", cria uma intrincada narrativa. Como diz Bond (1960, p.599), as suas reconstruções, exceto o epodo 1 da Fábula da Raposa e da Águia, são talvez hipotéticas demais para serem incluídas em uma edição. ${ }^{31}$ Diríamos o mesmo de Adrados (1981) que, até certo ponto, segue Lasserre. Luria (1930) também reconstruiu o epodo de Arquíloco a partir de uma série de fábulas. Além das duas citadas acima (Esopo 38 e 39 Chambry) que, a seu ver, seriam narradas no final do epodo, o enredo incluiria uma disputa pelo trono (da qual participavam o macaco, o elefante e o camelo, Esopo 146 Chambry), e a vitória do macaco (Esopo 307 Chambry). Immisch (1930) critica o complicado enredo de Luria mas não propõe interpretação menos difícil, pois privilegia a fábula sobre o macaco e os seus antepassados em Bábrio (81), sugerindo a emenda de týlen ("calo"), em vez de pýgen ("bunda"), no fragmento 187W de Arquíloco: quando a raposa faz objeção ao "calo" do macaco, esse responderia que o herdara de seus ancestrais.

Percebe-se logo, devido à variedade de leituras propostas, que partir das fábulas existentes em Esopo sobre o macaco e depois vasculhar todos os fragmentos de Arquíloco que nos restaram para construir narrativas semelhantes é trabalhar às avessas: os resultados, além de pequenos, são altamente hipotéticos. Não é possível saber quantas fábulas de Arquíloco tinham o macaco como protagonista, nem até que ponto se assemelhariam às fábulas esópicas. Após examinar os fragmentos de Arquíloco e as

\footnotetext{
${ }^{26}$ Schneidewin (1838), Bergk (1882-1915), Hauvette (1905, p.258), Luria (1930), Immish (1930), Edmonds (1931), Diehl (19523), Lasserre-Bonnard (1958), Gerber (1970).

27 Alguns, como Schneidewin (1838, p.192), supõem tratar-se de Licambes. Nesse caso, teríamos um segundo codnome para a mesma figura. Segundo Schneidewin (loc. cit.), os fragmentos 185, 201 e $187 \mathrm{~W}$ pertenceriam a uma única fábula no qual o poeta

caçoava do orgulho de Licambes (Fastum Lycambae deridebat).
${ }_{28}$ Hauvette (1905, p.258), Edmonds (1931), Treu (1959), Gerber (1970, p.38 considera, além dessa fábula, Esopo 14 e $246 \mathrm{H}$ como paralelos possíveis), Campbell (1983, p.130), Burnett (1983, p.65), Schadewalt (1989, p.118), West $\left(1989^{2}\right)$.

${ }_{29}$ Há um problema textual em Esopo: em vez de pugh/n (bunda), como no Schol. Ach 120 citado a seguir, Schneidewin (1838) sugeriu yuxh/n (44 Halm) mas, nos manuscritos G Pb, Mb e Pc, lê-se tu/xhn (cf. Perry, 1952, p.353), e no manuscrito Ia, mwri/an (38 Chambry). Isso levou alguns editores a modificarem o texto de Arquíloco fr.187W (cf. yuxh/n Bergk 1882, Hiller 1890, Edmonds 1931), mas no verso de Aristófanes (Ach.119), logo antes da paródia, há menção de um qermo/boulon prw/kton, o que reforça o argumento a favor de pugh/n.

${ }^{30}$ Schol. Arist. Ach. 120: Kail tou=to par\%/dhken e)k tw=n A)rxilo/xou e)p\%dw=n: toia/nde d ) w)= pi/qhke thln pughln e)/(xeij (E), ou e)/xwn (Lh).

${ }^{31}$ Cf. também Gerber (1970, p.37). Crusius (1895, p.299ss apud Hauvette 1905, p.258 n.5) cita a fábula dos macacos que dançam a pírrica (Esopo 360 Halm).
} 
principais interpretações propostas, parece-nos, porém, que a melhor alternativa - se quisermos compará-los a alguma fábula esópica - é a sugestão da fábula do macaco eleito rei e que é preso pela raposa em armadilha (Esopo 38 Chambry, 81 Perry). No entanto, não fica claro por que o macaco está só, nem por que vai para o "fim do mundo" (Arq. Fr. 185.4-5W). O aînos de Arquíloco seria diferente. Que a raposa, ao encontrar o macaco, medite algum artifício, explica-se pela sua inveja. Ela o levaria à armadilha e,

\section{fr. $186 \mathrm{~W} \quad \mathrm{r}(\mathrm{o} / \mathrm{ptrwi}$ e)reido/menon}

apoiando-se no gatilho

o macaco ficaria preso. Então, a raposa, com sua bela cauda e inteligência, perguntaria algo como:

fr. $187 \mathrm{~W} \quad$ toih/nde d ) w)= pi/qhke thln pughln e)/xwn

"Ó macaco, e com essa bunda" você queria ser rei?

Talvez seja mais vantajoso, para o comentário desses textos de Arquíloco, estudar a caracterização da raposa e do macaco em outras fontes antigas, particularmente a do macaco que nesse poema é o alvo. Dessa forma, se não pudermos reconstruir o enredo, pelo menos teremos uma idéia de que modo o poeta ataca sua vítima nesse jambo.

\section{O ÊTHOS DO MACACO E DA RAPOSA 32}

A caracterização de animais na cultura grega não é fixa, permanecendo sempre a mesma. Vimos que a astúcia da raposa, por exemplo, passou a ser denegrida principalmente quando essa forma de inteligência (mêtis) foi associada à dos sofistas em determinados círculos. Simônides, em sua sátira misógina, arrola os diversos tipos de mulheres comparando-as com os animais. Na verdade, o que faz é atribuir as características de cada espécie a uma mulher, sendo o seu poema uma fonte importante para os caracteres convencionalmente atribuídos a esses animais no sexto século a. C.. Se, ao descrever a mulher-raposa, Simônides não a qualifica como "astuta" (kerdaléos), é possível que isso se dê porque, para ele, isso seria um elogio - coisa que ele reserva apenas para a casta e trabalhadora "mulher-abelha". Ao ler esses versos, fica também evidente como os aspectos negativos da raposa puderam ser facilmente aplicados mais tarde aos sofistas por seus adversários (Simônides fr. 7.7-11):

thln d ) e)c a)litrh=j qeolj e)/qhk ) a)lw/pekoj

gunai=ka pa/ntwn i)/drin: ou)de/ min kakw=n

le/lhqen ou)deln ou)del tw=n a)meino/nwn:

tol meln galr au)tw=n ei)=pe polla/kij kako/n,

tol d ) e)sqlo/n: o)rghlnd ) a)/llot ) a)lloi/hn e)/xei.

Outra [mulher] o deus fez da malvada raposa,

mulher sabe-tudo. Nada mau

nem bom a escapa,

pois diz que algo é ora mau,

ora bom, e o seu temperamento é mutante.

Qual o êthos do macaco na Grécia antiga? Se no Egito o macaco era o animal sagrado do deus Thot, patrono dos escribas e estudiosos e, na Índia, um semideus que encarnava a "virtude máxima do heroísmo e da fidelidade da população autóctone a serviço do Rama", sendo reverenciado juntamente com a vaca e o elefante (MASPERO, 1997, p.305 e também KELLER,1963, p.7), na Grécia, desde o início, o macaco nunca gozou de boa reputação. Em Arquíloco (185W) não temos certeza do desfecho da fábula, mas em todas as demais fontes antigas, desde as arcaicas até as bizantinas e medievais, o macaco é considerado, no mínimo, como uma cópia imperfeita do ser humano.

Em primeiro lugar, fisicamente, o macaco foi sempre para os gregos o mais feio dos animais. ${ }^{33}$ Destacando esse traço, o retrato que Simônides faz de sua "mulher-macaco" reúne admiravelmente quase todas as características que encontraremos espalhadas nas demais fontes (fr. 7.71-82):

thln d ) e)k piqh/kou: tou=to dhl diakridoln

Zeulj a)ndra/sin me/giston w)/pasen kako/n.

ai)/xista meln pro/swpa: toiau/th gunhl

ei)=sin di ) a)/steoj pa=sin a)nqrw/poij ge/lwj:

e)p ) au)xe/na braxei=a. kinei=tai mo/gij,

a)/pugoj, au)to/kwloj. a)= ta/laj a)nhlr

o(/stij kakoln toiou=ton a)gkali/zetai.

$\mathrm{dh} /$ nea del pa/nta kail tro/pouj e)pi/statai

w(/sper pi/qhkoj: ou)de/ oi( ge/lwj me/lei:

ou)d ) a)/n tin ) eu)=e)/rceien, a)llal tou=t ) o(ra=i

kail tou=to pa=san $\mathrm{h}(\mathrm{me} / \mathrm{ran}$ bouleu/etai,

o(/kwj ti kw(j me/giston e)/rceien kako/n.

e uma (criou) do macaco. Esse foi o maior mal

\footnotetext{
${ }^{32}$ Agradeço a Sylvia Milanezi pelo texto de Lissarrague (1997, p.455-72) e pelas indicações de fontes referentes ao macaco na Antigüidade clássica.

${ }^{3}$ Cf. Píndaro ( $P$. II.73) : "o macaco é belo para os seus filhos, / sempre belo" (isto é, só um macaco para achar o outro belo), ou "o macaco é belo para as crianças,/ sempre belo" (porque crianças não teriam juízo ou senso estético, ou porque gostam do que é engraçado, ridículo).
} 
que Zeus concedeu aos homens

Medonha de cara, tal mulher

é motivo de riso para todos na cidade.

Tem pescoço curto, anda com dificuldade,

sem bunda, é só perna. Pobre do homem

que abraça semelhante mal.

Ela conhece todas as artes e os trejeitos

como um macaco, e nem liga para o riso alheio.

Não faz nenhum bem, mas só isso procura

e quer o dia inteiro:

saber como fazer o maior mal

Como Tersites que escolheu o destino de um símio, a mulher-macaco é hedionda: ela não tem pescoço e, o que é mais notável, também manca, como ele, provocando o riso. ${ }^{34}$ Como notou $\mathrm{H}$. Lloyd-Jones (1975, p.82, n.74), essa mulher é o contrário do orador na Odisséia (8.173) que é admirado como se fosse um deus por quem o vê caminhando pela cidade. $O$ fato da "macaca" ser criticada por não ter bunda (ápygos) esclarece a pergunta que a raposa, dona de um belo rabo, faz ao macaco feio e tolo que se deixou prender na armadilha na fábula de Esopo (81 Perry ${ }^{35}$ : como é que ele, sem bunda, poderia ser rei? Pois na Grécia esse era um critério de beleza importante não só para mulheres (cf. Lloyd-Jones, 1975 p.83, n.76) ${ }^{36}$, mas provavelmente também para os rapazes. Tendo por base a aristocrática associação entre beleza e nobreza (kalòs kagathós), a fábula assim nos diz (indiretamente) que a raposa é que deveria reinar. $^{37}$

Artesãos sempre revelaram as semelhanças existentes entre o macaco e o homem, o que também despertou o interesse dos filósofos, naturalistas e médicos antigos. O macaco era considerado como uma imitação mal feita do homem, tanto física, quanto espiritualmente: uma caricatura. Segundo Galeno (De usu partium I.80-81 Kuhn), "rimos das imitações que são fiéis na maior parte dos detalhes, mas falsas quanto ao essencial", e é justamente por isso que o corpo do macaco é uma "imitação ridícula" (mimêma gelô̂on) do corpo humano. Platão (Hípias Maior 289a-b) ${ }^{38}$ diz que, segundo Heráclito: "comparado a um deus, o mais sábio dos homens parece um macaco, em sabedoria e beleza, em tudo o mais". ${ }^{39}$ Embora o macaco se pareça conosco, ele está para o homem como o homem está para o deus. Assim também, o autor anônimo latino do Tratado de Fisionomia (124) diz:

Simia est animal malignum, ridiculum, turpe. Qui ad huius animalis speciem referuntur erunt

parui, cauis oculis, malae barbae, breuibus ceruicibus, paruorum oculorum, rugosi uultus,

imitatores ingeniorum alienorum, ipsi imperfectum ingenium habentes.

O macaco é um animal maligno, ridículo e feio. Os que correspondem a essa espécie de animal serão

pequenos, terão olhos afundados, barbas feias, pescoços curtos, olhos pequenos, rostos enrugados, e

imitarão as disposições naturais alheias, as suas próprias sendo imperfeitas.

Além de já ser, ele próprio, uma imitação, é da natureza do macaco imitar tudo o que vê. A mulher-macaco de Simônides repete "todas as maneiras e todos os trejeitos", não se importando de ser ridícula, um objeto de escárnio e riso alheio. Passar vergonha em público era tão insuportável para os gregos que, segundo conta a lenda, Licambes e suas filhas teriam se enforcado, não resistindo aos ataques dos jambos de Arquíloco. ${ }^{40} \mathrm{O}$ macaco pode ser ensinado a tocar instrumentos musicais, a dançar, a conduzir carros (Eliano, N.A. 5.26) ${ }^{41}$, e a única fábula em que ele leva a melhor e a é a do Macaco e do Camelo (Esopo 306 Chambry), onde ele o supera na dança.

Se o macaco é capaz de aprender "truques e artes", trata-se, porém, sempre de uma imitação sem inteligência. Jean Frère (1998, p.80) aproxima a imitação do macaco à forma que Platão $(R$. 397a) considera como sendo a pior, onde se imita tudo diante dos outros sem pudor. Horácio (Odes 1.10.18) também faz troça de um poeta que, segundo ele, "imita como um macaco". Pois a mimêsis do macaco é bufonaria que, somado à sua aparência, desperta o riso. Galeno (De usu partium I.80-81 Kuhn), detecta o elemento cômico do macaco no fato de ele tentar imitar as ações humanas e, a certa altura, enganar-se, errar. Mas como o macaco não sabe o que faz, a sua imitação pode ter conseqüências graves. Eliano (N.A. 7.21) diz que os macacos são as criaturas mais malinas (kakoethéstaton), ${ }^{42}$ especialmente quando imitam os homens, e ele narra a seguinte anedota como exemplo: o macaco observava a ama banhando uma

\footnotetext{
${ }^{34}$ Entre os deuses, o andar do coxo Hefesto também faz rir (Il.1.599-600). Cf. Aristides (ii.397.2 Dindorf) que diz que os macacos em Arquíloco são panoûrgoi, poikíloi, e que desejam o poder real (philoneikía basileías). Para macacos panoûrgoi, veja também Aristóteles (HA 488b20). É curioso que esses adjetivos sejam mais tarde atribuídos também à raposa.

5 Isso também serve como mais um argumento a favor de pýgen na fábula de Esopo (38 Chambry) e em Arq. 187W (cf. Aristófanes Ach.119-120).

${ }^{36}$ Lloyd-Jones (loc. cit.) arrola fontes sobre a pygé como critério de beleza : Hesíodo (Erga 373), Aristófanes (Pax 69b, Eccl.964-5), Ateneu (554c) e Alífron (4.14), citando Säflund (1964) para mais referências.

${ }^{37}$ Para o valor que as raposas davam às suas caudas, cf. a fábula de Esopo 41 (Chambry).

${ }^{38}$ Platão (Hípias Maior 289a-b): a)nqrw/pwn o( sofw/tatoj prolj qeoln pi/qhkoj fainei=tai sofi/\# kail ka/llei kail toi=j a/)lloij pa=sin. Aqui o macaco é "feio e tolo"; vincula-se a aparência à essência.

${ }^{39}$ Veja porém Plínio o Velho (11.246) para o macaco como uma cópia perfeita do homem em termos físicos.

${ }^{40}$ Cf. o fragmento $172 \mathrm{~W}$ de Arquíloco no qual o "pai Licambes", insensato, torna-se motivo de riso para todos na cidade. Em Simônides (supra), porém, a malvadeza da macaca é intencional, ao contrário das demais fontes que geralmente a tem como o

${ }^{41} \mathrm{Na}$ Na Grécia e Roma antiga, os macacos eram domesticados e serviam de entretenimento (Maspero, 1997, p.303)
${ }^{4}$.

${ }^{42}$ Para Eliano (N.A 17.39), os macacos, salvo uma espécie indiana, são malignos (kakóethes). Quando Aristófanes (R. 708) xinga Clígenes de "macaco", alude à feiúra e às traquinagens da personagem. Para as imagens relacionadas ao macaco em Aristófanes, onde ele é "habitualmente símbolo do fourbe", veja Taillardat (1965, p.228). Cf. também Eubulo (fr.114.4).
} 
criança. Quando ela saiu, ele despiu o bebê como a viu fazer e despejou sobre ele uma chaleira d'água que havia sido deixado sobre o fogo. Como a água estava fervendo, o bebê morreu.

As artes do macaco podem voltar-se contra ele, a sua imitação sem ciência pode levando-o à ruína. Com toda sua bazófia e fanfarronice, no fim, ele geralmente é vítima de um animal mais inteligente, ou de sua própria estultice. Para aprisionar macacos, por exemplo, os caçadores exploravam justamente esse seu pendor para a imitação. ${ }^{43} \mathrm{Na}$ Fábula do Macaco e dos Pescadores (Esopo 304 Chambry), qual aprendiz de feiticeiro, o macaco, após prender-se nas redes, admite: "recebi o que merecia, pois tentei pescar sem saber" (mê mathôn). Em outra fábula (Esopo 305 Chambry), o golfinho salva do naufrágio um macaco que tomou por um ser humano. Quando o macaco vangloriou-se de pertencer a uma família nobre e o golfinho descobriu que nem gente ele era, só de raiva, o golfinho mergulhou para o fundo, afogando-o. Aqui, como nas fábulas da raposa e do macaco, o macaco é pretensioso (Esopo 38 Chambry) e quer passar pelo que não é, mentindo acerca de sua nobreza (Esopo 39 Chambry).

O macaco também tem como atributo típico a hipocrisia, a mentira e a falsidade: é um ator de comedia bufa. Luciano (Piscator 32), por exemplo, critica os falsos filósofos, esses charlatães que, "embora sejam macacos, têm coragem de vestir a máscara de herói”. Os falsários, porém, como o macaco na fábula de Esopo (38 Chambry), traídos por seus apetites, sempre acabam revelando a sua verdadeira natureza (Piscator 36):

Le/getai del kail basileu/j tij Ai)gu/ptioj piqh/kouj potel purrixi/zein dida/cai kail tal qhri/a -mimhlo/tata de/ e)sti tw=n a)nqrwpi/nwn - e)kmaqei=n ta/xista kail o)rxei=sqai a(lourgi/daj a)mpexo/mena kail proswpei=a perikei/mena, kail me/kri ge pollou= eu)dokimei=n thln qe/an, a)/xri dhl qeath/j tij a)stei=oj ka/rua u(pol ko//pon e)/xwn a)fh=ken ei)j tol me/son: oi( del pi/qhkoi i)do/ntej kail e)klaqo/menoi th=j o)rxh/sewj, tou=q )o(/per h)=san, pi/qhkoi e)ge/nonto a)ntil purrixistw=n kail sune/tribon tal proswpei=a kail thln e)sqh=ta katerrh/gnuon kail e)ma/xonto peril th=j o)pw/raj prolj a)llh/louj, tol del su/ntagma th=j purri/xhj diele/luto kail kategela=to u(pol tou= qea/trou.

Conta-se também que, certa vez, um rei egípcio ensinou macacos a dançarem a pírrica. Os animais - pois são os maiores imitadores dos homens - aprenderam rapidíssimo e dançaram trajando mantos púrpura e máscaras sobre o rosto. O espetáculo, por muito tempo, ia bem, até que um espectador muito vivo, ${ }^{44}$ que tinha nozes no bolso, as lançou para o meio dos macacos. Esses, ao vê-las, esqueceram-se da dança e voltaram a ser o que eram, macacos em vez de dançarinos. Quebraram as máscaras, rasgaram as roupas e lutaram uns com os outros por causa dos frutos. A coreografia foi desfeita, surtindo o riso dos espectadores.

Fontes antigas também caracterizam o macaco como um "bajulador" e demagogo. Aristófanes (R. 1085-86) diz que a cidade está repleta de burocratas (hypogrammatéoi) e de políticos que ele chama de "enganadores demomacacos bufos" (bomolólkhon demopithékon/ eksapatónton). Se em seu ensaio "Sobre a Fortuna" (Mor. 97d) Plutarco tem como próprio à natureza dos macacos a bufonaria (bomololkía). Em "Como distinguir o bajulador do amigo" (Pl. Mor. 64e), ele pergunta:

$o($ (I\#=j toln pi/qhkon; ou) du/natai thln oi)ki/an fula/ttein w(j ku/wn, ou)del basta/zein w(j o( $\mathrm{i} /(\mathrm{lppoj}$, ou)d $)$ a)rou=n thln gh=n w(j o (bou=j: u(/brin ou)=n fe/rei kail bwmoloxi/an kail paidia=j a)ne/xetai kail ge/lwtoj o)/rganon e)mpare/xwn e(auto/n.

"Vês o macaco? Não pode guardar a casa como um cão, nem servir de transporte como o cavalo, nem arar a terra como o boi. Suporta, porém, ultraje, bufonarias, troça, e oferece a si próprio como instrumento de riso. Assim é o bajulador..."

E talvez fosse isso que Artemidoro (2.12) tivesse em mente quando dizia que, nos sonhos, o macaco representa as pessoas malignas que vivem ao nosso redor. A crueldade do macaco com sua própria cria aparece na Fábula dos filhos dos macacos (Esopo 307 Chambry). E por ser feio e maligno, uma deformação física e moral do homem, mais tarde, o macaco foi comparado ao próprio diabo na iconografia cristã e nos bestiários medievais, a concupiscência e a avareza sendo acrescentadas aos seus traços característicos (Maspero, 1997, p.305).

Ao classificar os macacos, Aristóteles (P.A. 689b30-5) aponta para a sua condição "fronteiriça" que é relacionada à sua falta de bunda ou de rabo: o ser humano, bípede, tem bunda mas não tem rabo; os quadrúpedes têm rabo mas não têm bunda; o macaco, porém, por ter uma "forma indeterminada" e "pertencer às duas espécies, não tem bunda nem rabo". Não tem rabo porque é bípede, nem bunda porque é quadrúpede. ${ }^{45} \mathrm{O}$ que é um problema classificatório para Aristóteles é hediondo para os gregos do ponto de vista estético, e é admirável o número de autores antigos que fizeram comentários sobre a "bunda" do macaco. Lissarrague (1997, p.468), em artigo que discute a representação do homem, do macaco e do sátiro no mundo antigo, traça relações entre os dois últimos que são criaturas de natureza ambígua, a meio caminho entre o homem e o animal: enquanto o sátiro é "um homem que se animaliza", o macaco é "um animal que se humaniza".

Tersites é um homem que, no Mito de Er (Platão, R. 620c), opta por ser macaco, o filósofo reconhecendo em sua figura as características típicas desse animal. Na Iliada (2. 212ss), Tersites, "o mais odioso dos homens que foi a Tróia", além de medonho, é o mais insensato: sua língua não tem freio e tudo o que faz é motivo de zombaria. Ele, que nem herói é, insulta Agamémnon macaqueando o discurso de Aquiles. Quem the dá uma surra corretiva, fazendo as tropas rirem, é Odisseu, justamente o mais astuto (kerdaléos) dos homens. Na República (loc. cit.), por ser gelotopoiós, surtindo o riso como um

\footnotetext{
${ }^{43}$ Cf. Diodoro da Sicília (17.90.2-3), Eliano (NA 17.25), Estrabão (15.699) e Plínio (HN 8.215).

${ }^{44}$ Note o uso do adjetivo ásteios ("citadino", "esperto"), para qualificar aquele que desmascara os macacos.

${ }^{45}$ Aristóteles (PA 689b30-5): o( del pi/qhkoj dial tol thln morfhln e)pamfoteri/zein kail mhdete/rwn t ) ei)=nai kail a)mfot/erwn, dial tou=t )

ou)/t Jou)raln e)/xei ou)/t ) )i))sxi/a. Veja Sófocles (Ichneutai, fr.314, v.128) para o andar do macaco com a bunda levantada no ar.
} 
macaco, esse poneròs idiótes - é assim que Platão o descreve no Górgias 525e - escolhe uma forma de vida semelhante ou pior que a sua. ${ }^{46}$ Em contraste, o que faz a opção mais sábia, vindo logo depois de Tersites, é Odisseu que, na Ilíada, o havia castigado por agir - como o macaco das fábula esópicas - como se fosse rei (Esopo 145, 38 Chambry), ou nobre (Esopo 39 Chambry).

Outros seres transformados em macacos, mas não por opção pessoal, são os Cercopes. Em um resumo das viagens de Enéias, Ovídio descreve a metamorfose sofrida pelos Cercopes, antigos habitantes da ilha dos Pithecusae. Jupiter, irado com as fraudes e perjúrios dessa raça dolosa, "os varões mudou em animal desforme", ao mesmo tempo "dissímeis do homem e símeis [a este]” (Ovídio Met. 14.91-100): ${ }^{47}$

quippe deum genitor, fraudem et periuria quondam

Cercopum exosus gentisque admissa dolosae,

in deforme viros animal mutavit, ut idem

dissimiles homini possent similesque videri,

membraque contraxit naresque a fronte resimas

contudit et rugis peraravit anilibus ora

totaque velatos flaventi corpora villo

misit in has sedes nec non prius abstulit usum

verborum et natae dira in periuria linguae:

posse queri tantum rauco stridore reliquit.

Sim, pois o genitor dos deuses, outrora desgostoso da fraude e perjúrios dos Cercopes e dos acometimentos de uma gente dolosa, os varões mudou em animal deforme, para que os mesmos pudessem parecer dissímeis do homem e símeis [a este]; contraiu-[lhes] os membros, contorceu para frente as narinas semi-curvas e rasgou com rugas de ancião o rosto; vedados por veludo fosco em todo o corpo, nesta sede meteu-[os]. Primeiro, porém, tolheu [-lhes] o uso das palavras e da língua nascida para duros perjúrios; revelou tão-só o poder de queixar-se com rouco estridor."

Em outras versões do mito, os Cercopes eram irmãos que maltratavam os viajantes. Segundo Zenóbio (Athous 2.85, Miller Mélanges 367), a mãe dos Cercopes os havia avisado para que tomassem cuidado com o melanpýgos (o que tem "bunda" ou "costas" negras). Quando Hércules os prendeu e, amarrando-os de pés juntos, os carregava sobre os ombros, dependurados de ponta-cabeça, os Cercopes riram da sua "bunda (ou "costas"?) negra".48 Na versão de Plutarco (quomodo. adul. 18 p.60c), Héracles achou graça e os deixou partir. Mas em um manuscrito do Suda,49 o herói fica furioso e arrebenta a cabeça deles contra o chão, em outro manuscrito, eles são petrificados.50

Os Ceropes eram figuras populares na comédia,51 e há noticia de um jambo em que eles são chamados Andoulo e Atlanto. O nome Cercopes (kerkós + óps) significa "cara de rabo" ou "cara de falo" (o que deve ter sido explorado pelos comediógrafos), e é curioso que esses gigantes bufos e malignos52, segundo o escólio a Licófron (688), sejam transformados em macacos, criaturas pequenas e feias, particularmente de "bundas feias", que dão o nome à sua ilha: Pithecusae ("a ilha dos macacos").

Poderíamos, talvez, comparar os Cercopes aos Ciclopes. Na Odisséia, o polymêtis Odisseu, kerdaléos qual uma raposa, é um instrumento de justiça divina. Como as vítimas dos Cercopes, ele e os seus homens sofrem injustiça nas mãos de um monstro à margem do mundo civilizado. Sem assembléias (Od. 9.105ss), os Ciclopes moram isolados, cada qual em sua caverna, desconhecendo qualquer forma de lei, cultura, ou organização social. Embora sejam pastores, eles não praticam a navegação ou a agricultura. Essas criaturas de dimensões titânicas, diferentemente dos "homens que comem pão", "comem cru", carne crua, como (aparentemente) o macaco da fábula de Esopo (38 Chambry).53 Os Ciclopes são perfeitos idiótai, vivendo quase como feras selvagens. Confiando na sua inteligência, Odisseu consegue libertar-se e vingar os companheiros mortos. Isso ele faz privando o Ciclope da visão e, com um astucioso trocadilho, tornando inútil a fala do monstro - pois ninguém compreende o seu pedido de socorro.

Tanto os Cercopes, quanto os Ciclopes, não temiam os deuses nem obedeciam às leis de hospedagem, matando os viajantes que passavam por suas ilhas. São gigantes, monstros do ponto de vista físico e moral, que vivem "nos confins" (an'eskhatíe), punidos por heróis civilizadores (Odisseu e Hércules), ou pelo próprio deus. Se no caso dos Cercopes há metamorfose, e o Ciclope perde a visão, o que há de comum entre os mitos é o fato de todos perdem o poder de se comunicarem, traço que destingue o ser humano dos animais no mundo não-fabuloso (cf. Konstan, 1991). Os gritos dos Cercopes, após transformados em macacos, "não fazem sentido" e só servem para protestar, assim como os do Ciclope que, por artifício de Odisseu, tornam-se incompreensíveis, ininteligíveis para os demais falantes, perdendo a função principal da língua que é comunicar.

\footnotetext{
${ }^{46}$ Cf. também Platão (R. 590b), onde o macaco é associado à bajulação (kolakeía) e à condição servil (aneleuthería): a supremacia da parte apetitiva da alma (thumoeidés) cria um macaco, em vez de um leão. É interessante que Platão contraste esses dois animais: pois o macaco (=Tersites) não pode rivalizar com um leão (=Agammémnon), já que, ao contrário do filósofo-rei no qual domina a pois o macaco (=Tersites) não pode rivalizar com um
parte intelectiva, ele é escravo dos próprios apetites.

${ }_{47}$ Tradução de Prof. Marcos Martinho dos Santos (DLCV/FFLCH/USP).

${ }^{48}$ Qual seria a graça se fossem "costas" negras? Por outro lado, o que significa exatamente ter uma "bunda-negra", além de evocar o próprio nome dos Cercopes ("cara de rabo")?

Cod. Coislin. 177, de Paroem. I.119, Suda, sv. (ed. Bernhardy).

${ }_{50}$ Para melanpýgos e o provérbio melampýgou týkhois, veja o fragmento $178 \mathrm{~W}$ de Arquíloco.

${ }^{51}$ Cf. Eubulo, Hermipo e Menipo (Meineke I.363, III 229; II.393; I.494), e Harpocrátio (s.v. Kérkopes).

52 O termo "cercopes" é empregado metaforicamente para "trapaceiro" e "velhaco" em Ésquino (2.40), Galeno (14.648), Diógenes Laércio (9.114) e Eustácio (1430.35).

3 Alguns comentadores estranharam que na armadilha a isca para o macaco fosse "carne".
} 
Macacos, sátiros, Cercopes e Ciclopes habitam essa região de fronteira entre o homem e o animal, entre a vida civilizada e a selvagem. É nessa região que Arquíloco situa o inimigo que ele ataca nesse jambo. Como outros, suponho que o poeta se esconde na pele da raposa54 que, como Odisseu e as demais raposas esópicas, denunciam a fraude, castigando o inimigo através do ridículo. Assim, a vítima nesse jambo de Arquíloco não é uma figura cômica, não provoca o riso deliberadamente (como o poeta), mas é o objeto de escárnio, desprezo e troça.

\section{BIBLIOGRAFIA}

ADRADOS, F. R. El mondo de la lirica griega antigua. Madrid, 1981.

ANONYME LATIN. Traité de physiognomonie. Texte établi et traduit par André, J. Paris, 1981.

BERGK, T. Poetae lyrici graeci. vol II. Leipzig, 1882 (1915).

BOND, G. W. Resenha de Archiloque, fragments. Texte établi par F. Lasserre, traduit par F. Bonnard, Paris: 1958).In: Gnomon 32. Paris, 1960. p. 596-600.

BOSSI, F. Studi su Archiloco. Bari, 1990.

BURNETT, A. P. Three archaic poets: Archilochus, Alcaeus, Sappho. London, 1983.

CAMPBELL, D. A. The golden lyre; the themes of the greek lyric poets. London, 1983.

CARVALHO FRANCO, M. S. "Escrita e oralidade; aspectos de uma teoria da linguagem em Platão,

Fedro 274c-276", conferência proferida no simpósio A Escrita no Mundo Antigo (MAE, USP, 1998).

CHAMBRY, E. (ed. \& trad.) Esope: fables. Paris, 1960.

COHOON, J. W. \& H. LAMAR CROSBY. Dio chrysostom. London, 1961.p.85.

CORREAA, P. da CUNHA. Armas e Varões; a guerra na lírica de Arquíloco. São Paulo, 1998a. A escrita na fábula de Arquíloco. In: Revista da Anpoll 4 (1998b).p. 249-262.

CRUSIUS, O. Aus der geschichte der fabel. In: KLEUKENS, C. H. Buch der fabeln. Leipzig, 1913.

DENNISTON, J. D. D. The greek particles. Oxford, 1954.

DETIENNE, M. \& J.-P. VERNANT. Les ruses de l' intelligence, la mètis des grecs. Paris, 1974.

DIEHL, E. Anthologia lyrica graeca. Leipzig, 1926, 1936, 1952.

EDMONDS, J. M. Greek elegy and iambus. London, 1931.

FOWLER, R. L. The nature of greek lyric.Tthree preliminary studies. Toronto, 1987.

FRÈRE, J. Le bestiaire de Platon. Paris, 1998.

GERBER, D. E. Euterpe: an anthology of early greek lyric, elegiac and iambic poetry. Amsterdam,1970.

HAUVETTE, A. Archiloque, sa vie et ses poésies. Paris, 1905.

HILLER, E. Anthologia lyrica graeca sive lyricorum graecorum veterum praeter Pindarum. Leipzig, 1890.

HOFFMANN, O. Die griechischen dialekte in ihrem historischen zusammenhange (III): Der Ionische Dialekt. Göttingen, 1898.

HUSCHKE. De fabulis Archilochi. In: Furia, Fabulae Aesopicae. Leipzig, 1810.

IMMISCH, O. Ein Epodos des Archilochos. Sitzungsber. D. Heielberger Akad. D. Wiss. Philo-hist. Klasse, Jahrgang 1930/31, 3 Abhandlung.

KELLER, O. Die Antiket tierwelt. Hildesheim, 1963.

KONSTAN, D. What is greek about greek mythology?. In: Kernos 4,1991.p. 11-30.

LASSERRE, F. Les épodes d' Archiloque. Paris, 1950.

LASSERRE, F. \& A. BONNARD. Archiloque: fragments. Paris, 1958.

LIEBEL, I. Archilochi reliquiae. Leipzig, 1812.

LISSARAGUE, F. L'homme, le singe et le satyre. In: L'animal dans l'Antiqiuté. Paris, Cassin, B. \& J. L. Labarrière, 1997. p.455-472.

LLOYD-JONES, H. Females of the species. London, 1975.

LURIA, S. Der Affe des Archilochos und die brautwerbung des Hippokleides. In: Philologus 85,1930. p. $1-22$.

MASPERO, F. Bestiario Antico. Parma, 1997.

PAGE, D. L. Archilochus and the oral tradition. In: Archiloque, entretiens sur l' antiquité classique X. Genève, Fond. Hardt,1964. p. 117-64.

PERRY, B. E. Aesopica I, II. Urbana Illinois, 1952.

RANKIN, H. D. Archilochus of paros. New York, 1977.

SÄFLUND, G. Aphrodite kallipygos. 1964

SCHADEWALT, W. Die fruehgriechische lyrik III. Frankfurt am Main, 1989.

SCHNEIDEWIN, F. G. Delectus poesis graecorum elegiacae, Iambicae, melicae. Göttingen, 1838.

TAILLARDAT, J. Les Images d'Aristophane; études de langue et de style. Paris, 1965.

TARDITI, G. Archiloco. Roma, 1968.

TREU, M. Archilochos. München, 1959.

WEST, M. L. Iambi et Elegi Graeci ante Alexandrum Cantati I. Oxford, 1971, 1989. In: Greek lyric poetry. Oxford, 1993.

\footnotetext{
${ }^{54}$ Cf Crusius (1913, p.xi): "vor allem tritt der kluge Reineke, hinter dem sich meint der Dichter selbst verbringt."
} 